\title{
Culture Wars
}

THE MEDIA AND THE BRITISH LEFT

JAMES CURRAN, IVOR GABER

AND JULIAN PETLEY

EDINBURGH UNIVERSITY PRESS 
(C) James Curran, Ivor Gaber and Julian Petley, 2005

Edinburgh University Press Ltd

22 George Square, Edinburgh

Typeset in Linotype Palatino

by Iolair Typesetting, and

printed and bound in Great Britain by

Antony Rowe Ltd, Chippenham, Wilts

A CIP record for this book is available from the British Library

ISBN 0748619178 (paperback)

The right of James Curran, Ivor Gaber and Julian Petley

to be identified as authors of this work

has been asserted in accordance with

the Copyright, Designs and Patents Act 1988.

Published with the support of the

Edinburgh University Scholarly

Publishing Initiatives Fund.

The Griffin's Eye cartoon is reproduced by kind permission of Charles Griffin; cartoon supplied by the Centre for the Study of Cartoons and Caricature, University of Kent.

The swastika cartoon is reproduced by kind permission of Associated Newspapers. 